\title{
Patriotism Among Multi-Ethnic Youths in Malaysia
}

\author{
Abdul Aziz Abdul Rahman ${ }^{1}$, Abdul Razaq Ahmad ${ }^{2}$ \& Mohd Mahzan Awang ${ }^{3}$ \\ ${ }^{123}$ The National University of Malaysia, MALAYSIA \\ E-mail: $\underline{\text { abdulazizar113@gmail.com }}$
}

\begin{abstract}
This study was conducted to determine the youth's perspective on social participation towards the practice of patriotism as well as racial tolerance among the youth from various ethnic groups in Malaysia. The purpose of this study was to examine the contribution of social participation towards the appreciation of patriotism measured using the constructs of feeling proud as a Malaysia, loyal to the nation, sense of belonging, discipline, efforts and productivity. The study is conducted in the form of reviews using questionnaire that can be distributed quickly and efficiently to obtain the data from respondents. Multiple regression analysis was conducted to identify the contribution of social participation variables towards the practice of patriotism among Malaysian youths. Multiple regression analysis (stepwise) shows that social participation variable is the construct that have the most significant correlation $(p<0.05)$ towards the practice of patriotism. The variables of social participation contributed 3.4 per cent towards the practice of patriotism among Malaysian youths $(\beta=$ $0.220, t=9,029$ and $\mathrm{p}=0.000)$ as well as the highest predictor towards the practice of racial tolerance $(\beta=0.293, t=13.725$ and $p=0.051)$ with 34.40 percent. This finding clearly shows the importance of social participation in various activities and programmes to foster a unity spirit among youths. The efforts to encourage the participations of youths from various ethnicities background have to be consistently pursued and enforced especially through promotion via social media as they are Alpha generation.
\end{abstract}

Keywords: Youth, social inclusion, patriotism, racial tolerance

\section{Introduction}

The process of social acceptance, the appreciation towards the elements of diversity, compromise attitude and social adaptation among Malaysians has actually slowly and consistently grown since the 50s on the basis of awareness from multi-racial leaders towards the importance of unity. The founding of the Rukun Negara, which is the heart of the nation's philosophy symbolizes the unity of the people to hold on to the same foundation regardless of ethnicity, culture and way of life.

In establishing the values of interdependence among the various ethnic groups, mutual acceptance and respect are the key elements that must be maintained by avoiding any element of prejudice, provocation and provoking elements of racial sensitivity that can incite conflicts and polemics. Unity should be nurtured and preserved for generations while patriotic spirit should be instilled in the souls of all citizens through exemplary living practices which uphold the rules of living and working together to contribute to a safe, prosperous which would not attract unobtrusive element that can disrupt the peace and harmonity of a society.

The main challenge in this regard is how to increase the social participation among various races in community activities to ensure that there is a strong bond as a nation which loves the country and being together contributing to its 
progress regardless of race, ethnicity and religions. The patriotic spirit is nurtured through practices and modelling which was passed down from old to new generations by eliminating any sense of racial prejudice towards the values of disciplined, caring souls, respecting as well as enhancing social inclusion by seeking more similarities without being influenced by foreign elements that has been trying to destroy unity that has been around for so long.

The prosperity of a country can be maintained if all citizens have high patriotic values and spirit. According to Nazri and Jamsari (2002), patriotism means unconditional love for the nation and is ready to contribute to the advancement of the nation. When there is a sense of love for the country, one will become a good citizen.

However, according to Nordin Kardi (2009), the awareness and patriotism soul can change with the passage of time. Sometimes it can go up to a high level but can also depleted and becomes fragile. Therefore, a stable social environment must exist to maintain the patriotic spirit of the people, especially the youth, in order to contribute significantly towards the development of the nation and the country as a whole.

\section{The Background of Multi-Ethnicities in Malaysia}

Malaysia is built on the understanding of the various ethnic groups which inhabit it. History also reveals how the wisdom of past leaders had built their nation's foundations through the concept of good relations between various ethnic groups. Therefore, Mohamad Rodzi Abdul Razak (2009) stated that the formation of Malaysia as a nation requires that every ethnic group is prepared to accept, recognize and compromise the differences that exist. This is because with the diversity of ethnic groups in our country, various issues can arise that can lead to conflict. Only through compromise value can the solution be achieved through effective negotiations for the sake of love towards our country. The culture of unrest and tension that has taken place overseas has heightened awareness among Malaysians on the importance of creating unity and maintaining it forever.

The third Malaysian Prime Minister, Tun Hussein Onn, once emphasized that Malaysia can achieve harmony if it is able to deal with the four main constructs that are related to each other. These are politics, economics, unity, and security. Even if only one of the constructs fails, the country will be in a state of instability.

Malaysia is an independent nation with a diverse community of people comprising of different religions, races, languages, cultures and customs. These diversities are a key challenge in achieving the country's successful mission towards achieving the status of a developed nation by 2020 (Osman Bakar, 2006).

Multi-ethnic relations in Malaysia were already strengthened through social contracts that were mutually agreed upon when Malaysia was formed with the understanding of all races to accept Islam as a federal religion, Malay as the national language and the Federal Constitution as the core that have to be respected and accepted as a citizen of the nation.

\section{Patriotic Values Among Youths}

A stable and harmonious nation is built on the spirit of love and awareness among the people. All Malaysians realize that through unity, our country can move forward towards achieving its 2020 vision goal. The progress of the nation will not be possible if the people of this country are not united, always bickering and in the face of conflict over racial and prejudiced issues that are intentionally spreading around.

The younger generation and youth as the future heirs of the nation need to have the knowledge and awareness towards the concept of inter-ethnic relations in order to continue the legacy of the social contract that has been accepted and adopted since the beginning of the country's independence. This is important, so that the younger generation and the youth are not influenced by the narrow racial agenda that could undermine the values of unity which could trigger conflict and threaten the nationalist entity which will destabilize the country's politic and economic sector. The understanding and upholding the value of unity should be promoted as early from pre-school to higher education to formulate the national agenda in the spirit of the young generation in order for them to engage in social relations with other ethnicities without inciting any issues nor problems.

Patriotic values need to be shaped in children, adolescents and youths in order to maintain the social stability and prosperity of the country that were already enjoyed today as well as to prevent any subversive elements that could interfere with the country's stability and harmonity among its citizens. The spirit of patriotism exemplified by previous generations who were willing to sacrifice to defend the country is a great example to be showed to the younger generations.

\section{Issues and Conflicts}

Today's young generation is increasingly exposed to social media which opens the thinking box of the younger generation. There are a number of youths who have begun to 
erode the spirit of patriotism which could affect on the efforts to build a sense of identity and belonging among the nation's youth. A high interest in hedonism and k-pop culture has infiltrated the minds of the youth to appreciate the cultural heritage of the nation and can trigger serious cultural polemics.

Malaysian society consists of various ethnic groups such as Malay, Chinese, Indian, Iban, Kadazan, Bajau, Orang Asli, Penan, Punan, Bidayuh, Orang Ulu, Bajau, Murut, Melanau, Bisayan, Kenyah and others. Due to the diversity of these backgrounds, the political landscape in Malaysia is interspersed with racist struggles (Ishak Saat, 2010). One of the reasons for the deterioration of the unity in Malaysia is due to the fact that it is a multiracial society (Zaid Ahmad, 2010).

Wan Hasni Murni et al., (2013) pointed out that historical elements play a very important role in fostering patriotism among youths to strengthen their identity as Malaysians, but youths are becoming less concerned on historical elements which lead to their shallow in knowledge in nation's history. This can be daunting because the youths will be vulnerable towards extreme thought and can be colonized by the futile foreign culture.

Social involvement and participation in activities that involve multiple ethnic groups need to be developed so that social relationships can develop in the context of a multiracial society rather than a separate ethnic group that can cause separation and impede unification.

\section{Previous Studies}

According to the Ministry of Youth and Sports (2004), youth is defined as those who were aged in the range of 15 to 30 years $(\geq 15$ and $\geq 30)$. Ezhar Taman et al (2006) believes that youth can act as the agents to ensure that the country's harmony and unity are maintained. This can be achieved through social participation and the willingness to interact with multi-racial communities.

Schatz et al. (1999) thinks that patriotism can be divided into two perspectives: blind patriotism and constructive patriotism. The perspective of blind patriotism is a state of non-critical support towards the action of a group. However, constructive patriotism (also known as critical patriotism) is a critical awareness on the importance of loyalty to a group. In the context of living in a multiracial society, the emphasis on racial terms can raise sensitive issues so that the best way forward is to rebrand the multiethnic groups as Malaysians. This means that people form various races are capable to mix with one another without any boundary.
Although Malaysian youths are regarded as the future heirs and leaders of the country, the youth often receive negative media coverage as a generation which are unwilling to fullfill the aspirations of the nation. According to Shamsul Amri (2010), among the problems that are faced by Malaysia today are linked to the error of claiming similarity between social and and economic solidarity. The key characteristics of unity are failed to be understood, including elements of assimilation, accommodation, acculturation and amalgamation. The assumption is often given that if the sharing of economic pie as planned through the NEP is successful, then Malaysia will automatically achieve national unity. However, the results were not as expected. If this harmonious ethnic relationship is compromised then Malaysia's goal as a one nation country is also challenged despite its satisfactory economic growth and political stability.

Abdul Rahim (1999), argues that the instillation of love for the country is a process in developing personal and attitude, emotions, interpersonal skills, social awareness as well as practicing the good life values. Furthering the process of socialization to overcome the existing challenges, the education system has become a key means of producing young Malaysian with one nation identity and is patriotic. and raising awareness of patriotism (Chua Kheng Hoe, 2007).

\section{Research Methodology}

The purpose of this study was to examine the contribution of social participation towards the patriotism practice in relation to several constructs which were proud to be Malaysian, loyal towards the nation, sense of belonging, discipline, hardworking as well as productivity. This study is in the form of reviews using a set of questionnaires that can be distributed quickly and efficiently to get the data from respondents.

The questionnaire used in this study have 7 Likert point scale as it gives the respondents greater variety and thus reflects continuous range of responses in obtaining the data (Colman, Norris \& Preston, 1997). The variables of social participation in this study refer to the Social Model (Putman, 2001) while patriotic behavior refers to the framework of Patriotism by MOE (2000).

The sample selection was conducted randomly based on zones namely North, East, South and Central Zones. Sampling is a research strategy which allow researchers to obtain information about a population of individuals who represent the total population (Cohen et. al 2007).

\section{Finding}

Multiple regression analysis was conducted to identify the contribution of social participation variables towards 
patriotic behaviour among Malaysian youths. Before the multiple regression analysis is carried out, the researcher first verifies whether the distribution of scores of questionnaires is linear or not by means of residual scatter plot and regression normal plot which was obtained from the subprogram 'Linear Regression'. Researcher used stepwise multiple regression analysis as suggested by Hair et al. (1995).

Table 1: The Contribution of Social Participation towards Patriotic Behaviour and Racial Tolerance among Malaysian Youths

\begin{tabular}{|c|c|c|c|c|c|c|c|}
\hline \multirow[b]{2}{*}{$\begin{array}{l}\text { Variabl } \\
\text { e }\end{array}$} & \multirow{2}{*}{\multicolumn{2}{|c|}{$\begin{array}{l}\text { Unstandard } \\
\text { ized } \\
\text { Coefficients } \\
\text { Stand } \\
\text { ard } \\
\text { B Error }\end{array}$}} & \multicolumn{2}{|c|}{$\begin{array}{l}\text { Standar } \\
\text { dized } \\
\text { Coefficie } \\
\text { nts }\end{array}$} & \multirow[b]{2}{*}{ Sig. } & \multirow[t]{2}{*}{$\mathbf{R 2}$} & \multirow[t]{2}{*}{$\begin{array}{l}\text { Contrib } \\
\text { ution }\end{array}$} \\
\hline & & & Beta & $\mathbf{T}$ & & & \\
\hline Social & 0.15 & 0.01 & & & .00 & 0.0 & $3.4 \%$ \\
\hline \multirow{3}{*}{$\begin{array}{l}\text { Particip } \\
\text { ation }\end{array}$} & 8 & 7 & 0.220 & 9.029 & 0 & 34 & $(\mathrm{~PB})$ \\
\hline & 0.25 & 0.01 & 0.293 & 13.7 & 0.0 & 0.3 & $34.4 \%$ \\
\hline & 8 & 9 & & 25 & 51 & 44 & $(\mathrm{RT})$ \\
\hline PB & $=$ & Patri & & iour & & & \\
\hline RT & $=$ & Raci & Toleran & & & & \\
\hline
\end{tabular}

Multiple regression analysis (stepwise) shows that social participation has the highest correlation as well as significant contributor ( $p<0.05)$ towards patriotic behaviour. The variables of social participation contributed 3.4 per cent towards patriotic practice among Malaysian youths $(\beta=0.220, t=9,029$ and $p=0.000)$. This shows that as the social participation score increased by one unit, the patriotism practice is also increased by 0.220 units. This shows that social participation among the youth is a vital factor in contributing to their patriotism.

The main predictor of racial tolerance practice among Malaysian youths was social participation $(\beta=0.293$, $\mathrm{t}=13.725$ and $\mathrm{p}=0.051)$ and their contribution was 34.40 percent. This finding clearly shows that social participation is a major contributor towards the practice of racial tolerance among Malaysian youths.

\section{Research Impact}

This study was conducted to determine the perspective of youths on social participation in promoting patriotic behaviour and racial tolerance among the youths from various ethnic groups in Malaysia.

This finding clearly shows the importance of social participation in various activities and programmes to foster a unity spirit among youth. Through the participation from various races, they will be able to interact, get to know each other and play a positive role in contributing towards the harmonity, the progress of the nation and the prosperity of the nation. The old stigma on ethnic centric is no longer an issue because assimilation of various ethnic groups into one nation will become a priority.

The effort in promoting youth participation from in various activities with their peers from other ethnic groups should be pursued consistently through the promotion via social media platform to increase their awareness on positive perception through a good communication network between people. This study is in line with the study by Mohd Anuar Amri \& Mohammad Aizat Jamaluddin (2011) who stated that Malay, Chinese and Indian youths often held social activities together in workplaces and universities without any problems. This shows that the youth are more open in accepting the differences that exist among them.

The study also showed that social participation associated with various youth activities in the community with other ethnic partners was the dominant factor contributing to racial tolerance which is 34.4 percent. To enhance racial tolerance, various parties need to make effort in engaging with various activities involving various ethnic groups as it has been identified as the main factor that can contribute to racial tolerance.

The findings of this study support the study conducted by Fatimah Daud (2004) who have seen the extent to which youth interact and socialised within a campus community and also influence their way of interacting with more complex external community structures.

\section{Conclusion}

The willingness to accept and adapt between ethnicities and cross-culture is a key element in building a new face of Malaysians (Bangsa Malaysia). The initial challenge in building a nation of Malaysian Malaysia is the concept and unity practice that was still foreign that mind changing is needed in order to accept, appreciate, recognize and adapt each other as a nation and no longer on an ethnic basis. The multicultural community, especially the youths, can live in peace and practice their beliefs and cultures independently while respecting one another. Social participation without racial and religious segregation among youths has facilitated the national integration process in the country. This group is more open and no longer influenced by racial sentiment.

\section{References}

[1] Abdul Rahim Abdul Rashid. (1999). Wawasan dan Agenda Pendidikan. Kuala Lumpur. Utusan Publication \& Distributors Sdn. Bhd. 
[2] Chua Kheng Hoe. (2007). Pembangunan Patriotisme DalamPengajaran dan Pembelajaran Matapelajaran Sejarah Tingkatan Dua. Bangi: UKM

[3] Colman, A.M, Norris, C.E dan Preston, C.C., 1997. Comparing Rating Scales of Different Lengths: Equivalence of Scores from 5-Point and 7-Point Scales. Psychological Report, 80, 355-362.

[4] Cohen, L., Manion, L. \& Morrison, K. 2007. Research Methods in Education. 6th ed. London: Routledge.

[5] Ezhar Tamam, Fazilah Idris, Wendy Yee Mei Tien, Azimi Hamzah, Rezal Hamzah, 2006. News media socialization and ethnic tolerance among youth in malaysia. Kertas kerja ini dibentangkan di 15th AMIC Annual Conference Anjuran The Asian Media Information and Communication Center pada 17-20 July 2006, Pulau Pinang, Malaysia

[6] Fatimah Daud, 2004. Polarisasi kaum di kalangan pelajar-pelajar universiti. Kuala Lumpur: Jabatan Antropologi \& Sosiologi, Fakulti Sastera \& Sains Sosial, Universiti Malaya.

[7] Hair, J. F., Jr., Anderson, R. E., Tatham, R. L. and Black, W. C. 1995. Multivariate Data Analysis, 3rd ed, Macmillan Publishing Company, New York

[8] Ishak Saat, 2009. Malaysia 1945-2000. Siri Pengajian Sejarah. Kuala Lumpur: Utusan Publications \& Distributors Sdn. Bhd.

[9] Kementerian Belia dan Sukan (KBS), 2004 Pelan Tindakan Pembangunan Belia Nasional. Kementerian Belia dan Sukan, Putrajaya.

[10] Kementerian Pendidikan Malaysia (KPM), 2000. Model Patriotisme. Kuala Lumpur: KPM

[11] Mohamad Rodzi Abd Razak, 2009. Pembinaan Negara Bangsa Malaysia: Peranan Pendidikan Sejarah dan Dasar Pendidikan Kebangsaan. Jebat: Malaysian Journal of History, Politics and Strategic Studies, 36. pp. 90-106

[12] Mohamed Anuar Ramli \& Mohamad Aizat Jamaluddin. (2011). 'Uruf Majmuk: Konsep dan amalannya di Malaysia. Jurnal Fiqh. 8, 45-64 Journal of Fiqh, No. 8 (2011) 45-64.

[13] Nazri \& Jamsari, 2002. Patriotisme: Konsep dan pelaksanaannya di Malaysia. Dlm Seminar Antarabangsa Nilai dalam Komuniti Pasca Modenisme (SIVIC 2004). Langkawi.

[14] Nordin Kardi, 2009. Ke Arah Penubuhan Majlis Patriotisme Negara. Dlm Abdul Aziz (Ed.), Patriotisme Kemandirian Kita (Pertama., hlm. 67-86). Kedah: Institut Pemikiran Tun Dr. Mahathir Mohamad Universiti Utara Malaysia.

[15] Osman Bakar. 2006. Dialog Antara Agama di Malaysia: Satu Pertimbangan. Kertas ini dibentangkan dalam syarahan umum di Majlis Syarahan \& Diskusi anjuran IKD-KAF anjuran Institut Kajian Dasar di Petaling Jaya pada $15 \mathrm{hb}$ Disember 2006.
[16] Putnam, Robert D, 2001. Social capital. Measurement and consequences, Canadian Journal of Policy Research 2:41-51

[17] Schatz RT, Staub E, Lavine H. 1999. On the varieties of national attachment: blind versus constructive patriotism. Political Psychology 20, 151-174.

[18] Shamsul Amri Baharuddin, 2010. Dasar Ekonomi Baru (DEB) Dan Implikasi Terhadap Hubungan Etnik Di Malaysia", wacana anjuran Jabatan 24 Pengajian Islam dan Kemanusiaan, Pusat Bahasa dan Pembangunan Insan, Universiti Teknikal Malaysia Melaka

[19] Zaid Ahmad, 2010. Pengenalan Hubungan Etnik di Malaysia Secara Umum. Dlm N. M. Zaid Ahmad, Ruslan Zainuddin, Sarjit Singh Gill, Ahmad Tarmizi Talib, Ho Hui Ling, Lee Yok Fee, Najeemah Mohd Yusof (Ed.), Hubungan Etnik di Malaysia (Kedua.). Shah Alam: Oxford Fajar. 